\title{
Relationship between perceived organizational support and organizational citizenship behavior on go-jek's employees and drivers
}

\author{
Ratna Maharani Hapsari* \\ ratna_m@staff.gunadarma.ac.id \\ Gunadarma University, J1. Margonda Raya 100, Depok, 16424, Indonesia
}

\begin{abstract}
This research aims to determine the relationship between perceived organizational support and organizational citizenship behavior on Go-Jek's employees and drivers. The total number of respondents are 32 people, who works as Go-Jek's employees and drivers. To measure the organizational citizenship behavior (OCB), the researcher used an organizational citizenship behavior (OCB). This measuring instrument has a reliability of 0,875 with a total number of 15 items. Meanwhile, to measure the perceived organizational support (POS), the researcher used a perceived organizational support (POS). This measuring instrument has a reliability of 0,931 with a total number of 21 items. Based on the results of the hypothesis test results, it is known that there is a positive relationship between perceived organizational support and organizational citizenship behavior on Go-Jek's employees and drivers with a significance coefficient value of 0,029 $(\mathrm{p}<0,05)$.
\end{abstract}

Keywords: Organizational Citizenship Behavior, Perceived Organizational Support

\section{Introduction}

Currently transportation is important for the public, its usage can also be done online. The existence of online transportation in Indonesia can facilitate public's life sustainability to do daily activities. The rapid development of technology makes many people create new employments for the community, one of them is PT. Gojek Indonesia since 2010.

PT. Gojek Indonesia is one of the start-up companies that received the title of unicorn, where this company is one of the largest online transportation service providers in Indonesia. Surely the application offered by GoJek must be easy to understand and use by various groups of people, and to develop this convenience it is expected that Go-Jek's employees and drivers can contribute their best innovations at work.

When the employees work, naturally, they will feel very comfortable if the company is able to provide support to its employees, so that the employees feel trusted and will voluntarily give their best at work for the company, even though they have to do work beyond their ability.

The behavior of these employees is called organizational citizenship behavior (OCB). According to Pangarso (2016) organizational citizenship behavior (OCB) is a behavior that is done by someone to fulfill 
organizational goals and is not rewarded for what he has done. Employees who have a high organizational citizenship behavior (OCB) have a high expectation for their organization, where employees feel that the work can make the organization has a good progress for the company and employees always prioritize the interests of the organization rather than personal interests. This is very beneficial for the organization because the presence of employees who have an organizational citizenship behavior (OCB) can improve the quality of organizational effectiveness (Organ, 2006).

According to Organ (1995), there are six factors that influence a person's OCB behavior namely organizational climate culture, personality and mood, perceptions of organizational support (POS), perceptions of the quality of superior-subordinate interactions, tenure, and gender. Organ (2006) said that the perceptions of organizational support (POS) is one of the factors that can affect someone's high and low in OCB.

Therefore, the role of organization in paying attention to the social and emotional needs of employees also the extent to which the organization establishes a good relationship between employees and the organization is called perceived organizational support. Perceived organizational support is defined as a feeling about the extent to which organizations value their contributions and care about their well-being (Eisenberger and Rhoades in Britt and Jex, 2014).

In a previous research conducted by Ali (2014), the result of the research obtained a correlation test result of 0,421 with a significant value of $0,000(p<0,01)$. This proves that the existence of organizational support (perceived organizational support) has a positive effect for employees to further engage with the organization.

\section{Research Method}

In accordance with the research objective which is to determine the relationship between Perceived Organizatonal Support (POS) and Organizational Citizenship Behavior (OCB) on Go-Jek's employees and drivers. The population in this research were Go-Jek's employees and drivers. Population is a generalization area consisting of objects or subjects that have certain qualities and characteristics determined by researchers to be studied and then to be drawn the conclusions (Sugiyono, 2017). The sampling technique in this research is by using a non- probability sampling, namely the snowball sampling technique, which is a technique for determining the sample which is initially small in number, then enlarges (Sugiyono, 2014). The researcher chose snowball sampling, because in determining the sample at first the researcher decided in only one or two people, but because the data obtained were deemed incomplete, the researcher looked for other people to complete the data through the help of the previous sample, in this research the total sample is as many as 32 people.

Data collection technique in this research is using a questionnaire. According to Gulo (2002) a questionnaire is a technique used by researchers to collect data by using an instrument to ask for responses from respondents regarding the matter to be studied.

The research instrument consists of three parts. The first part consists of demographic questions that include name/initial, gender, age, length of work, and division. The second part consists of instruments containing organizational citizenship behavior scale, and the third part consists of instruments containing perceived organizational support scale, where both scales use a Likert scale technique of 1 to 5 .

Distribution of the questionnaire was carried out on April 8, 2020 and the data was collected on April 21, 2020. The data collection process was conducted using a Google form which the researcher had distributed via WhatsApp. Overall, the process of distributing questionnaires had a few problems, due to the current condition that required Go-Jek's employees and drivers to work from home.

To measure an organizational citizenship behavior (OCB) the researcher uses the organizational citizenship behavior (OCB) scale which was adapted from Rahman (2017) based on the dimensions of organizational citizenship behavior developed by Podsakoff dan MacKenzie (1990) namely organizational citizenship behavior scale (OCBS) based on organizational citizenship behavior dimensions, i.e. altruism, 
civic virtue, courtesy, sportmanship, dan conscientiousness. This measuring instrument has a reliability value of 0,875 with a total of 23 items. After processing the data, it is known that eight items are declared invalid because they have an item discrimination power value below 0,3 , so that the total valid items are 15 items.

Table 1. Reliability Organizational Citizenship Behavior (OCB)

\begin{tabular}{cc}
\multicolumn{2}{c}{ Reliability Statistics } \\
\hline Cronbach's Alpha & N of Items \\
\hline, 875 & 15 \\
\hline
\end{tabular}

Meanwhile, to measure a perceived organizational support (POS), the researcher used the perceived organizational support (POS) scale adapted from Sholeh (2018) based on the dimensions of perceived organizational support made by Rhoades and Eisenberger (2002) namely fairness, supervisor support, and organizational rewards and job condition. This measuring instrument has a reliability value of 0,931 with a total of 26 items. After processing the data, it is known that eight items were declared invalid because they had an item discrimination power value below 0,3 , so that the total valid items are 21 items.

Table 2. Reliability on Perceived Organizational Support (POS)

\begin{tabular}{cc}
\multicolumn{2}{c}{ Reliability Statistics } \\
\hline Cronbach's Alpha & N of Items \\
\hline, 931 & 21 \\
\hline
\end{tabular}

The analytical technique used to test the hypothesis is a correlation technique with the help of an IBM SPSS Statistics Version 22 program. In this research, to test the power of item discrimination, the researcher used an Item Total Correlation analysis with the help of IBM SPSS Statistics Version 22 program. To test the reliability in this research, the researcher used Alpha Cronbach analysis with the help of the IBM SPSS Statistics Version 22 program.

\section{Results And Discussion}

Based on the hypothesis test results, it is known that there is a relationship between perceived organizational support and organizational citizenship behavior on Go-Jek's employees and drivers. It is proven by the calculation results obtained a significance coefficient value of 0,029 ( $p>0,05)$, so that the research alternative hypothesis is accepted. The relationship between perceived organizational support and organizational citizenship behavior on Go-Jek's employees and drivers has a positive direction, which means that the higher the perceived organizational support, the higher the organizational citizenship behavior.

Table 3. Correlation Coefficient

\begin{tabular}{|c|c|c|c|}
\hline \multicolumn{4}{|c|}{ Correlations } \\
\hline & & POS & OCB \\
\hline \multirow[t]{3}{*}{ POS } & Pearson Correlation & 1 &, $340^{*}$ \\
\hline & Sig. (1-tailed) & &, 029 \\
\hline & $\mathrm{N}$ & 32 & 32 \\
\hline
\end{tabular}

In this research, the organizational citizenship behavior scale has an empirical mean of 61,56 which is in the high category. This is because according to Organ (2006) employees who owns a high organizational citizenship behavior (OCB) have high hopes for their organization, where employees feel that the work can make the organization have a good progress for the company and employees always prioritize the interest of 
organization rather than personal interests.

Later on the perceived organizational support scale has an empirical mean of 79,65 which is in the high category. This is because the organization is very concerned about Go-jek's employees and drivers at work. Organizational support for Go-Jek's employees and drivers can include in the form of rewards, motivation, trust, and the organization's concern for the welfare of Go-Jek's employees and drivers. Rhoades and Eisenberger (2002) identify honesty, supervisor support, organizational rewards and good working conditions as organizational traits that have a positive effect on perceived organizational support. Organizational support for employees may include support in the form of financial and non-financial rewards such as motivation, reliability, trust, and concern from the organization or company for the welfare of its employees.

In this research, most respondents were male with a percentage of $62,5 \%(\mathrm{~N}=20)$, while another percentage of $37,5 \%(\mathrm{~N}=12)$ were female. This is in accordance with Tabassum's research (2016) which shows that sometimes men who are involved in OCB behavior may feel more obligated to be involved in organizational life than female employees. Based on age, respondents are in the age of 21-30 years old with a percentage of $53,1 \%(\mathrm{~N}=17)$. This is because at the age of 21-40 years old, Go-Jek employees still have a fairly strong physique to work hard so that they always help each other towards other Go-Jek employees. According to Jahangir, Akbar, and Haq (2004) young employees coordinate the employee needs with the more flexible of organizational needs. On the other hand, older employees tend to be more rigid in adapting their needs to the organization. Therefore, young and old employees may differ in their orientation to self, others and work. These differences may lead to different salient motives for organizational citizenship behavior (OCB) between young and old employees.

Respondent description results based on length of work were in the range of 1-3 years with a percentage of $71,9 \%$ ( $N=23$ ). According to Organ (2006), the employee's tenure will affect the employee's closeness to the company. A long working period will also increase self-confidence, lead to positive feelings and behaviors of employees in doing their jobs. The experience of a person carrying out work continuously can increase his technical maturity. The things that determine whether or not an employee is experienced as well as an indicator of work experience are working age, level of knowledge and skills and mastery of work and equipment.

Based on previous research conducted by Putra (2013), the results show that the relationship between Perceived organizational support and organizational citizenship behavior has a significant positive relationship. Therefore, an increase in the level of perceived organizational support will be followed by an increase in organizational citizenship behavior and vice versa. Thus, the better the perception of employees who feel they get perceived organizational support in the environment where employees work will be followed by high organizational citizenship behavior in question.

In addition, a previous research conducted by Intifada and Nurtjahjanti (2013) showed that there was a positive relationship between perceived organizational support and organizational citizenship behavior. Organizational support, be it's giving awards to employees will be able to create a commitment for employees to stay in the organization. The perceived organizational support provided by the organization to employees makes employees motivated to be in OCB behavior.

According to Organ (2006), the benefits of organizational citizenship behavior (OCB) for an organization are that it can increase the productivity of managers and co-workers, become an effective means to coordinate work-team activities effectively and maintain organizational performance stability. To improve an organizational citizenship behavior (OCB) in employees, there are several factors that can influence, one of the factors that can affect a person's high and low in OCB is the perception of organizational support (POS) (Organ, 2006). Putra (2013) defined that if employees think that organizational support really values employees, then employees will feel appreciated in the organization and their work so that employees want to help the organization to achieve its goals. If employees consider that the organizational support they receive is high, employees will also improve their work and have a positive perception of their company.

As stated by Rhoades and Eisenberger (in Organ, 2006) that organizations value employees who are 
dedicated, loyal to the organization, productive, and tend not to quit their jobs. Full support from the company for its employees makes every employee feel important and valued in the organization and his work so that employees want to help the organization to achieve its goals (Putra, 2013). This organizational support is given to improve their work behavior. The existence of organizational support provided by the organization to employees makes employees motivated to be in OCB behavior. (Intifada \& Nurtjahjanti, 2013).

\section{Conclusions and Suggestions}

Based on the results of data collection and analysis that has been conducted on 32 respondents, it is known that the results of the hypothesis are accepted, it can be concluded that there is a positive relationship between perceived organizational support and organizational citizenship behavior on Go-Jek's employees and drivers with a significance coefficient value of $0,029(\mathrm{p}>0,05)$. The relationship between perceived organizational support and organizational citizenship behavior on Go-Jek's employees and drivers has a positive direction, this means that the higher the perceived organizational support, the higher the organizational citizenship behavior.

Based on the results of the research that has been conducted, there are some suggestions that can be given as follows:

- Further researchers are also expected to consider the number of subjects who will be used as research respondents because in this research the respondents are still relatively small.

- Further researchers are expected to be able to research in other sectors besides employees at PT Go-Jek.

- Further researchers are expected to be able to dig deeper into other variables that might affect perceived organizational support and organizational citizenship behavior.

- Further researchers are expected to be able to see the surrounding conditions that are happening when they want to collect data.

\section{References}

Ali, H. M. (2014). Perceived organizational support and organizational citizenship behavior: the case of Kuwait. International journal of Business Administration, 5(3), 59-72.

Gulo, W. (2002). Metodologi penelitian. Jakarta: Gramedia

Intifada, R., \& Nurtjahjanti, H. (2013). Hubungan antara perceived organizational support dengan organizational citizenship behavior pada karyawan hotel pandanaran Semarang. Jurnal Psikologi Empati, 2(3), 1-9.

Jahangir, N., Akbar, M. M., Haq, M. (2004). Organizational citizenship behavior : its nature and antecedents. BRAC University Journal, $1(2), 75-85$.

Jex, S. M., \& Britt, T. W. (2014). Organizational psychology: a scientist practitioner approach third edition. United States of America: Wiley.

Organ, D.W., and Ryan, K. (1995). A Meta-Analytic Review of Attitudinal And Dispositional Predictors of Organizational Citizenship, Personnel Psychology, Vol. 48 No. 4, pp. 775-802.

Organ, D. W., Podsakoff, P. M., MacKenzie, S. B. (2006). Organizational citizenship behavior: Its nature, antecedents, and consequences. United States of America: SAGE.

Pangarso, A. (2016). Perilaku organisasi. Yogyakarta: Deepublish

Podsakoff, P. M., MacKenzie, S. B., Moorman, R. H., \& Fetter, R. (1990). Transformational leader behaviors and their effects on followers' trust in leader, satisfaction, and organizational citizenship behaviors. The leadership quarterly, 1(2), 107-142.

Putra, D. S. (2013). Hubungan antara perceived organizational support dengan organizational citizenship behavior pada karyawan PT En Seval Putera Megatrading divisi transportasi cabang Sidoarjo. Jurnal Psikologi Industri dan Organisasi, 2(1), 61-75.

Rahman, A (2017). "Pengaruh kepuasan kerja dan komitmen organisasional terhadap kinerja karyawan dengan organizational citizenship behavior sebagai variabel intervening di Puskesmas Mlati 2 Sleman D.I. Yogyakarta". Skripsi. Tidak Diterbitkan. Jakarta (ID): Universitas Gunadarma.

Rhoades, L., \& Eisenberger, R. (2002). Perceived organizational support: a review of the literature. Journal of applied psychology, 87(4), 698.

Sholeh, A. R. (2018). "Hubungan persepsi dukungan organisasi (perceived organizational support) dengan komitmen organisasi (organizational commitment) pada pegawai BLU UIN Sunan Ampel Surabaya". Skripsi. Tidak Diterbitkan. Surabaya: Universitas Islam 
Negeri Sunan Ampel.

Sugiyono. (2014). Metode penelitian pendidikan pendekatan kuantitatif, kualitatif, dan R\&D. Bandung: Alfabeta.

Sugiyono. (2017). Metode penelitian sosial. Bandung: PT Remaja Rosdakarya.

Tabassum, R. 2016. The Study of Relationship between Dimensions of OCB and Gender Diffrerence: A Literarture Review. International

Journal of Science Technology and Management. Vol.No.5. 